\title{
Recepcija i recenzije djela José Ortege y Gasseta u njemačkim časopisima u razdoblju Weimarske Republike
}

Damir Velički*

damir.velicki@ufzg.hr
UDK: 1 Ortega y Gasset, J. 050:82](430)"1919/1933“" Izvorni znanstveni rad / Original scientific paper

Primljeno: 10. svibnja 2016.

Prihvaćeno: 6. lipnja 2016.

Nakon teorijskih polazišta u kojima se razjašnjava pojam recepcije oslanjajući se na samu teoriju recepcije te njezine predstavnike, prije svega Jaussa i Isera te pojam recenzije, analiziraju se i povijesno-društvene situacije. Pritom se interes istraživanja sadržajno ograničava na recenzije, tj. prikaze knjiga španjolskog filozofa José Ortege y Gasseta u njemačkim časopisima koji su se bavili književnošću, i to u razdoblju Weimarske Republike, od 1919. do 1933. godine. Spoznaje o tome kakva su tumačenja djela nekog autora bila i u kojim su se časopisima ona objavljivala s obzirom na karakter, ideološku, odnosno vjersku orijentaciju tih časopisa, bacaju dodatno svjetlo i na sama djela, odnosno na autora u cjelini. Iz tog razloga bilo je potrebno temeljitije promotriti političku situaciju u Njemačkoj u navedenom povijesnom periodu. Nakon detaljne analize zaključeno je da je Ortega y Gasset u Njemačkoj u vrijeme Weimarske Republike, ako mjerimo prema nakladi časopisa, odnosno prodanih knjiga, definitivno pronašao svoj put do njemačke čitateljske publike.

Ključne riječi: José Ortega y Gasset, recepcija, časopisi za književnost, Weimarska Republika, filozofija.

\footnotetext{
" Doc. dr. sc. Damir Velički, docent na Katedri za obrazovanje učitelja njemačkog jezika - interkulturalna germanistika Učiteljskoga fakulteta Sveučilišta u Zagrebu, Savska cesta 77, HR10000 Zagreb.
} 


\section{Uvod}

\section{Recepcija je:}

"pojam koji su potkraj 1960-ih u književnu teoriju uveli zagovornici estetike recepcije sa Sveučilišta u Konstanzu. Za H. R. Jaussa recepcija je mjesto potvrđivanja estetske kvalitete književnog djela.«1

Dakle, kad je riječ o recepciji, ključno ime je Hans Robert Jauss koji je svojim djelom Literaturgeschichte als Provokation der Literaturwissenschaft ${ }^{2}$ (1967) otvorio novo poglavlje književne teorije. Estetika recepcije proučava načine na koje književno djelo postiže svoje efekte time što se opire ili udovoljava očekivanjima čitatelja. Sam čitatelj pak povezuje, ispunjava praznine i izvlači zaključke. Ključni Jaussov termin estetike recepcije je »horizont očekivanja« (Erwartungshorizont), kojim se označava pripravnost na književne postupke u okviru mentalnog vidokruga pojedinog čitatelja. Naime, novi tekst budi u čitatelju sjećanje na pojedinosti iz već poznatog horizonta očekivanja koji se onda mijenja ili samo reproducira.

Kada je riječ o estetici recepcije, svakako treba spomenuti i Wolfganga Ise$\mathrm{ra}^{3}$ Osnovu njegove teorije čini teza o čitanju kao stvaralačkom činu, a njegov glavni uzor je Roman Ingarden. ${ }^{4}$ Od njega je Iser preuzeo i termin »mjesto neodređenosti« (Unbestimmtheitsstelle), koji je od središnje važnosti za njegovu kritičku teoriju. Iser se slaže s Ingardenom da čitatelja ne treba shvatiti kao pasivnog promatrača i zalaže se za pojam konkretizacije, prema kojoj je čitatelj odgovoran za stvaranje estetskog predmeta iz književnog teksta. No Iser se ne slaže s Ingardenom u objašnjenju pojma tekstovne neodređenosti koji mu se ne čini utemeljen na dinamičnom načelu. Ingarden, naime, smatra da čitatelja ne pokreću neodređenosti i praznine, već same riječi u tekstu. Prema Iseru, tek mjesta neodređenosti omogućuju sudjelovanje čitatelja u stvaranju smisla jer takva mjesta otvaraju mogućnosti čitateljevoj djelatnosti. Među važne formalne uvjete za takvu djelatnost Iser navodi raznolikost iznesenih stavova u djelu koji se često sudaraju bez ikakva posredovanja. Odnos između takvih stavova Iser naziva krojem (Schnitt), a u odnosima između raznih stavova dolazi do praznina (Leerstellen) koje su osnovni činitelji za djelovanje nekog teksta. Iser polazi od toga da čitanje u svom procesu sadrži sjećanje na prošlost (čitanja).

Osim navedenih, i čitav niz drugih autora bavili su se recepcijom, spomenimo samo neke: Karl Robert Mandelkow koji smatra da postoji više različitih

\footnotetext{
${ }^{1}$ Nat. »recepcija«, u: S. KUTLEŠA (ur.), Filozofski leksikon, Zagreb, Leksikografski zavod »Miroslav Krleža«, 2012, 973.

${ }^{2}$ Usp. H. R. JAUSS, Literaturgeschichte als Provokation, Frankfurt - Main, Suhrkamp, 1970.

${ }^{3}$ Usp. W. ISER, Der Akt des Lesens. Theorie ästhetischer Wirkung, München, Wilhelm Fink Verlag, 1976.

${ }^{4}$ Usp. R. INGARDEN, Das literarische Kunstwerk. Mit einem Anhang von den Funktionen der Sprache im Theaterschauspiel (1931), Tübingen, Niemeyer, 1972.
} 
horizonata očekivanja koji utječu na proces recepcije, a to su horizont očekivanja epohe, očekivanja djela i očekivanja autora, ${ }^{5}$ Harald Weinrich, ${ }^{6}$ Gunther Grimm, ${ }^{7}$ te promišljanja o hermeneutici Hans Georga Gadamera ${ }^{8}$ prema kojoj je temelj razumijevanja »stapanje horizonata«. Iako kritizirana, Gadamerova se hermeneutika ipak mora spomenuti kada je riječ o proučavanjima interpretacije književnog teksta. Istovremeno treba istaknuti da je individualna recepcija već unaprijed određena tzv. društvenom recepcijom, odnosno materijalnim i idejnim posrednicima između djela i čitatelja. U to možemo ubrojiti nastavu književnosti, ali i različite društvene institucije, izdavačka poduzeća, knjižare, te književnu kritiku, odnosno recenzije tj. prikaze knjiga.

Upravo se u središtu interesa ovog rada nalaze odnosi između recepcije i općih svjetonazorskih pozicija, odnosno između prikaza knjiga, dakle recenzija te povijesno-društvene situacije iz čega se mogu izvući određeni zaključci o društvenopovijesnoj uvjetovanosti učinka nekog djela. Pritom se interes istraživanja sadržajno ograničio na recenzije, tj. prikaze knjiga španjolskog filozofa José Ortege y Gasseta u njemačkim časopisima koji su se bavili književnošću, a vremenski se ograničio na Njemačku u razdoblju Weimarske Republike, dakle u razdoblju od 1919. do 1933. godine. Međutim, prije prikaza rezultata istraživanja, valja istaknuti nekoliko aspekata.

Kada je riječ o recipijentima djela nekog autora, postoji nekoliko mogućnosti kako se oni mogu utvrditi. Može se tako, primjerice, istražiti tko su konkretno kupci knjiga, tj. čitatelji nekog autora, mogu se istražiti motivi koji su ih potakli na kupnju knjige ili čitanje djela, osobine njihovih ličnosti, stupanj obrazovanja, političke preferencije, čitalačke navike i dr. Takvo istraživanje bi, da je riječ i o suvremenom autoru, bilo vrlo opsežno i zahtjevno. Ako se pak radi o recepciji djela autora čiji je glavni period recepcije bio desetljećima unatrag i $\mathrm{k}$ tomu se još namjera istraživanja ograniči na vremenski period od prije 80 do 100 godina, onda je izvjesno da se navedene mogućnosti istraživanja recepcije više ne mogu realizirati.

Preostaje dakle pronaći izlaz u istraživanju posrednika recepcije, u ovom slučaju recenzija tj. prikaza knjiga koje su objavljene u časopisima koji se bave književnošću. Spoznaje o tome kakva su tumačenja djela nekog autora bila i u kojim su se časopisima ona objavljivala s obzirom na karakter, ideološku odnosno vjersku orijentaciju tih časopisa, bacaju dodatno svjetlo i na sama djela, odnosno na autora u cjelini. Pritom ne treba zaboraviti granice koje sadrži navedena metodologija istraživanja recipijenata Ortegina djela. U sljedećem

\footnotetext{
${ }^{5}$ Usp. K. R. MANDELKOW, Probleme der Wirkungsgeschichte, Jahrbuch für internationale Germanistik, 2 (1970) 71-84.

${ }^{6}$ Usp. H. WEINRICH, Für eine Literaturgeschichte des Lesers, Merkur, 21 (1967) 1026-1038.

7 Usp. G. GRIMM, Literatur und Leser. Theorien und Modelle zur Rezeption literarischer Texte, Stuttgart, Reclam, 1975.

${ }^{8}$ Usp. H. G. GADAMER, Wahrheit und Methode. Grundzüge einer philosophischen Hermeneutik, Tübingen, Mohr, 1964.
} 
koraku, a prije prezentacije rezultata istraživanja, valja se temeljitije osvrnuti na sam pojam recenzije odnosno prikaza knjige te na političku i duhovnu situaciju u Njemačkoj u vrijeme Weimarske Republike, odnosno od završetka Prvoga svjetskog rata do dolaska Hitlera na vlast 1933. godine.

\section{Recenzija i recenzent kao posrednik izmedu autora i čitatelja}

Prema definiciji Hrvatske enciklopedije Leksikografskoga zavoda »Miroslav Krleža«, recenzija (lat. recensio: pregledanje, prosuđivanje) jest pismena ocjena ili pismeni prikaz nekoga znanstvenog djela ili umjetničkog ostvarenja (recenzija knjige, kazališne predstave). ${ }^{9}$ Književna recenzija posreduje između autora djela i potencijalnih čitatelja, ona želi proizvesti komunikaciju i može znatno doprinijeti širenju kulture čitanja i znanja. Mogli bismo reći da književna recenzija nema samo društvenu, nego i političku funkciju, budući da pluralizam mišljenja i svjetonazora jest sastavni dio demokratskog društva. Ne smijemo zaboraviti da je općenito područje medija, a samim time i onih tiskovnih, često u izravnoj vezi s političkom klimom, odnosno političkim sustavom nekog društva.

Književna se recenzija obično sastoji od opisa sadržaja, biografskih podataka o autoru, te od kritičke percepcije djela prema osobnim estetskim mjerilima i iskustvima. Ona bi istovremeno trebala omogućiti potencijalnom čitatelju bolje razumijevanje djela. Terminološki gledano, recenziju se ne može potpuno poistovjetiti s književnom kritikom. Književna kritika je, kako ju je široko definirao Jaumann, »svaka vrsta komentirajuće, prosudbene, promidžbene i klasificirajuće izjave o književnosti, odnosno o onome što se smatra književnošću «. ${ }^{10}$

Ovoj definiciji koja polazi od toga da je književni kritičar svatko tko se izjašnjava o književnosti, ipak trebamo suprotstaviti polazište Petre Altmann da se književna kritika ne može svesti na osvrt na nova izdanja, nego isključivo na »opis i procjenu razvoja književnosti iz književnoznanstvene perspektive«. ${ }^{11}$ Altmann i Carlsson ${ }^{12}$ također ističu da se recenzija i književna kritika ne mogu poistovjetiti. Književna recenzija obraća se velikom broju čitatelja, ona pokreće dijalog između čitatelja i recenzenta, a pozornost koju može recenzija privući na sebe u javnosti ovisi ne samo o aktualnosti teme, nego i o ugledu i popularnosti recenzenta. Primjerice Petre i Škreb ističu važnost autoriteta kritičara, a recenzija se definira kao

\footnotetext{
${ }^{9}$ Nat. »recenzija«, u: www.enciklopedija.hr/ (02.05.2016).

${ }^{10}$ Usp. H. JAUMANN, Literaturkritik, u: H. FRICKE (ur.), Reallexikon der deutschen Literaturwissenschaft, sv. 2, Berlin - New York, De Gruyter, 2000, 463-468.

${ }^{11}$ P. ALTMANN, Der Buchkritiker in deutschen Massenmedien. Selbstverständnis und Selektionskriterien bei Buchbesprechungen, München, Univ. Diss., 1983, 23.

${ }^{12}$ Usp. A. CARLSSON, Die deutsche Buchkritik von der Reformation bis zur Gegenwart, Bern, Francke, 1969.
} 
»kritika u malom koja zbog manjeg obima ne može biti naročito iscrpna, a svoje tvrdnje potkrepljuje više autoritetom kritičara nego prikazom umjetničkih, idejnih itd. činjenica prosuđivane knjige.$^{13}$

Istovremeno treba istaknuti da recenzija, osim što potiče komunikaciju, može služiti i za njezinu kontrolu. Utoliko može postati i kao indirektno sredstvo cenzure, sredstvo koje državna politika može koristiti da bi znatno utjecala na javno mnijenje. Utoliko je potrebno, a budući da je $u$ fokusu ovog rada recepcija i recenzije djela José Ortege y Gasseta u njemačkim časopisima u vrijeme Weimarske Republike, temeljitije promotriti političku situaciju u Njemačkoj u navedenom povijesnom periodu.

\section{Politička i duhovna situacija u Njemačkoj u razdoblju od 1919. do 1933. godine}

Weimarskom Republikom opisuje se razdoblje njemačke povijesti od donošenja novog ustava 1919. godine pa sve do dolaska nacionalsocijalista na vlast 1933. godine, odnosno do imenovanja Adolfa Hitlera državnim kancelarom. Ustavotvorna Nacionalna skupština se nakon izbora u siječnju 1919. godine sastala 6. veljače 1919. u Weimaru, a ne u Berlinu. Razlog tomu bili su nemiri u Berlinu, a odabran je upravo Weimar kao jedno od najvažnijih središta njemačke kulture, grad u kojem su živjeli i djelovali brojni pisci, umjetnici i znanstvenici koji su dali neizmjeran doprinos ne samo njemačkoj, nego i europskoj odnosno svjetskog kulturi. Spomenimo samo neke: Johann Wolfgang von Goethe, Friedrich Schiller, Carl Zeiss, Friedrich Nietzsche, Paul Klee i brojni drugi. Nacrt novog ustava napravio je ugledni pravnik i političar Hugo Preuß, a Nacionalna je skupština konačnu verziju novog ustava prihvatila 31. srpnja 1919. Weimarski je ustav, nakon što ga je predsjednik Friedrich Ebert potpisao 11. kolovoza, stupio na snagu 14. kolovoza 1919. godine. Weimarski ustav dobio je u ono doba epitet »najdemokratskijeg « ustava na svijetu. ${ }^{14}$

Međutim, iako je ustav, između ostaloga, predviđao i mogućnost provođenja plebiscita, načelne odluke prepustio Reichstagu te u drugom dijelu detaljno opisao Temeljna prava i temeljne dužnosti Nijemaca, on je istovremeno predsjedniku, kao svojevrsnoj protuteži parlamentu, davao vrlo velike ovlasti. Ovlasti koje su omogućavale predsjedniku da u slučaju ugrožavanja javne sigurnosti i reda proglasi izvanredno stanje i pritom stavi izvan snage i neka temeljna prava. Naime, ako bi predsjednik ustanovio da je »znatno poremećena ili ugrožena javna sigurnost i poredak«, prema čl. 48. st. 2. smio je i temeljna prava

\footnotetext{
${ }^{13}$ F. PETRE, Z. ŠKREB (ur.), Uvod u književnost, Zagreb, Znanje, 1969, 550.

${ }^{14}$ Usp. R. SCHIFFERS, Elemente direkter Demokratie im Weimarer Regierungssystem, Düsseldorf, Droste Verlag, 1971.
} 
privremeno staviti izvan snage: npr. slobodu pojedinca (čl. 114), slobodu izražavanja (čl. 118), slobodu okupljanja (čl. 123), a također je prema čl. 48, st. 2. smio uključiti vojsku u rješavanje problema. ${ }^{15}$ Osim toga temeljem Zakona o zaštiti Republike (Gesetz zum Schutze der Republik) koji je donesen 1922. godine, te produžavan 1927. i 1930. godine, moglo se intervenirati i u izdavaštvo putem zabrana i cenzure. Povijest Weimarske Republike mogli bismo podijeliti u tri dijela. Razdoblje od 1919. do 1923. godine bio je obilježen krizama, hiperinflacijom, kao i brojim pokušajima političkog prevrata i političkim ubojstvima. Razdoblje od 1924. do 1929. godine bilo je razdoblje političke stabilnosti, to se razdoblje često naziva »zlatnim dvadesetim godinama « i njime se želi istaknuti privredni uzlet i procvat umjetnosti, kulture i znanosti. Taj je period završio svjetskom ekonomskom krizom 1929. godine, kada je počela i posljednja etapa Weimarske Republike, razdoblje ponovne ekonomske i političke nestabilnosti koje je rezultiralo dolaskom nacionalsocijalista na vlast.

Koliko je razdoblje Weimarske Republike bilo znanstveno i umjetnički plodno, između ostaloga svjedoči i činjenica da su Nijemci od 1919. do 1933. godine dobili ukupno petnaest Nobelovih nagrada, odnosno od ukupno trideset i šest Nobelovih nagrada za znanost koje su u tom razdoblju dodijeljene, respektabilnih dvanaest dobili su upravo njemački znanstvenici. ${ }^{16}$ Spomenimo samo neke: Max Planck (Nobelova nagrada za fiziku 1918. godine koju je primio 1919. godine), Albert Einstein (Nobelova nagrada za fiziku 1921. godine), te nadalje, da spomenemo neke i izvan područja prirodnih znanosti, Gustav Stresemann (Nobelova nagrada za mir 1926. godine, zajedno s francuskim političarem Aristide Briandom), ili pak Thomas Mann (Nobelova nagrada za književnost 1929. godine).

Iako je njemački časopis Der Schriftsteller 1922. godine na svojim stranicama objavio komentar »cenzura je ukinuta Weimarskim ustavom, ali čini se da ta činjenica još nije potpuno poznata našim sudovima «, ${ }^{17}$ čime je Društvo njemačkih književnika izrazilo svoje mišljenje o sudskoj praksi s početka 20ih godina 20. stoljeća, istovremeno treba naglasiti i zaključak do kojeg su s historijskim odmakom došli stručnjaci, da u vrijeme do stvaranja Weimarske Republike »nikada u njemačkoj povijesti nisu umjetnosti i znanosti bile tako slobodne $\ll^{18}$ Možemo navesti nekoliko ilustrativnih podataka. Tako je primjerice u vrijeme Weimarske Republike registrirano 7.152 pisaca. Ta se brojka, za razliku od popisa zanimanja koje je provedeno 1907. i 1933. godine, odnosi doista na pisce kao samostalnu grupu, a ne zajedno s urednicima i novinarima. Od

\footnotetext{
${ }^{15}$ Usp. D. VELIČKI, Njemački u politici. S njemačko-hrvatskim rječnikom političke terminologije i tumačenjem odabranih pojmova političkoga sustava Njemačke i Austrije, Zagreb, UFZG, 2015, 248-252.

${ }^{16}$ Usp. E. FISCHER (ur.), Geschichte des deutschen Buchhandels im 19. und 20. Jahrhundert, sv. 2, Weimarer Republik, 1. dio, München, K. G. Saur Verlag, 2007.

${ }^{17}$ Der Schriftsteller, 9 (1922), 8.

${ }^{18}$ H. SCHULZE, Weimar - Deutschland 1917-1933, Berlin, Severin und Siedler, 1982, 129.
} 
registriranih 7.152 pisca, njih 2662 (37 \%) bavilo se pisanjem kao sporednom djelatnošću, a njih 4.490 kao glavnom. Udio žena bio je 14,8 \%, od čega se 800 žena bavilo pisanjem kao glavnom, a 243 kao sporednom djelatnošću. ${ }^{19}$ Književne recenzije u Weimarskoj Republici bile su pretežito, dakle ne isključivo, zadaća stalno zaposlenih urednika i novinara.

Međutim, djelatnost književnog recenzenta u pravilu nije bilo glavno zanimanje. Kao preduvjet da bi novinar ili urednik dobio stalan posao, bilo je dvogodišnje volontiranje ${ }^{20} \mathrm{u}$ kojemu su se stjecale praktične vještine i učila pravila profesionalnog ponašanja, za što je u većim izdavačkim kućama obično bio zadužen glavni urednik. Već statistički podaci o broju novoizašlih knjiga i časopisa svjedoče o turbulentnim političko-društvenim okolnostima Weimarske Republike, odnosno o razdobljima političke stabilnosti. Kako je vidljivo iz tablice 1, nedostaju neki podaci. Tako npr. nema podataka za 1923. godinu, u kojoj je inflacija dostigla svoj vrhunac, ili pak nedostaju podaci za 1929. godinu kada je bila godina svjetske ekonomske krize. Osim toga, vidljivo je da je u razdoblju od 1926. do 1928., dakle u godinama koje se ubrajaju u »zlatne dvadesete«, broj novih knjiga i časopisa bio najveći.

U vrijeme političke nestabilnosti 1931. - 1932., neposredno prije dolaska nacionalsocijalista na vlast, broj novih književnih izdanja je u opadanju (usp. tablicu 1).

Tablica 1. Izdanja novih knjiga i časopisa u Njemačkoj 1913. - 1932. godine ${ }^{21}$

\begin{tabular}{|c|c|c|}
\hline Godina & Broj novih knjiga & Broj časopisa \\
\hline 1913. & 15.229 & 6.689 \\
\hline 1919. & & 3.886 \\
\hline 1921. & 16.826 & \\
\hline 1922. & 4.802 & \\
\hline 1926. & 13.602 & 6.739 \\
\hline 1927. & 14.814 & 6.860 \\
\hline 1928. & 13.617 & 7.116 \\
\hline 1930. & 13.317 & 7.303 \\
\hline 1931. & 11.797 & 7.469 \\
\hline 1932 & 10355 & 7652 \\
\hline
\end{tabular}

${ }^{19}$ B. SCHEIDELER, Zwischen Beruf und Berufung. Zur Sozialgeschichte der deutschen Schriftsteller von 1880. bis 1933, Berlin, De Gruyter, 1997, 28-34 i 207-210. i Statistik des Deutschen Reiches, 1927, 392, cit. u: H. SPEIER (ur.), Die Angestellten vor dem Nationalsozialismus: ein Beitrag zum Verständnis der deutschen Sozialstruktur 1918-1933, Göttingen, Vandenhoeck \& Ruprecht, 1977.

${ }^{20}$ Usp. W. HAGEMANN, Soziale Lage des deutschen Journalistenstandes. Eine Untersuchung des Instituts für Publizistik der Westfällischen Wilhelms-Universität Münster, Düsseldorf, Droste, 1956, 147-157.

${ }^{21}$ Izvor: E. UMLAUFF, Beiträge zur Statistik des deutschen Buchhandels, Leipzig, Börsenverein der deutschen Buchhändler, 1934, 62-65. 
Broj novina porastao je od 3.862 naslova 1920. godine na 4.4701932. godine, ${ }^{22}$ ali pritom treba naglasiti da je ovih $25 \%$ novina imalo nakladu od 1.000 do 5.000 primjeraka, ${ }^{23}$ a nešto manje od $50 \%$ novina su same sebe označavale stranački orijentiranim, odnosno čvrsto vezanim uz neku stran$\mathrm{ku} .{ }^{24}$ Novinarstvo nije svoju zadaću vidjelo samo u informiranju građanstva, nego uvelike i kao sredstvo propagiranja svoje ideologije i političkih stavova, a društvenom raslojavanju naročito su pridonijele ne samo desnoekstremistička, nego i lijevoekstremistička glasila. ${ }^{25}$ I časopisi koji su se bavili književnošću i objavljivali recenzije novih književnih izdanja mogu se razvrstati prema političkoj orijentaciji (tablica 2): ${ }^{26}$

Tablica 2. Politička orijentacija, naklada i izdavač književnih časopisa u Njemačkoj u razdoblju Weimarske Republike

\begin{tabular}{|c|c|c|c|}
\hline Naziv časopisa & $\begin{array}{c}\text { politička } \\
\text { orijentacija }^{27}\end{array}$ & naklada & Izdavač \\
\hline Die Aktion & $\begin{array}{c}\text { lijevo- } \\
\text { revolucionaran }\end{array}$ & 20.000 (1930.) & $\begin{array}{l}\text { Die Aktion, Berlin - } \\
\text { Wilmersdorf }\end{array}$ \\
\hline Der Sturm & $\begin{array}{c}\text { lijevo- } \\
\text { revolucionaran }\end{array}$ & 5.000 (1930.) & Herwarth Walden \\
\hline Die literarische Welt & lijevi centar & $\begin{array}{l}13.000(1926 .) \\
20.000(1932 .)\end{array}$ & Rowohlt (do 1928.) \\
\hline $\begin{array}{c}\text { Die Weltbühne (1905- } \\
1918 \text { časopis se zvao Die } \\
\text { Schaubühne) }\end{array}$ & lijevi centar & $\begin{array}{l}10.000(1925 .) \\
15.000(1930 .)\end{array}$ & $\begin{array}{c}\text { Verlag der } \\
\text { Weltbühne, osnivač } \\
\text { Siegfried Jacobsohn }\end{array}$ \\
\hline
\end{tabular}

\footnotetext{
${ }^{22}$ Isto.

${ }^{23}$ Usp. K. MOORES, Presse und Meinungsklima in der Weimarer Republik, Mainz, Univ. Diss., 1997, 32.

${ }^{24}$ Usp. W. HAGEMANN, Soziale Lage des deutschen Journalistenstandes. Eine Untersuchung des Instituts für Publizistik der Westfällischen Wilhelms-Universität Münster, Düsseldorf, Droste, 1956, 147-157.

${ }^{25}$ Isto.

${ }^{26}$ Izvor: J. KÜRSCHNER, Handbuch der Presse, Berlin, Hilger, 1902, digitalna verzija Robarts University of Toronto dostupna na https://archive.org (29.04.2016); F. SCHLAWE, Literarische Zeitschriften 1910-1933, Stuttgart, J. B. Metzlersche Verlagsbuchhandlung, 1962; H. KESSLER, Wilhelm Stapel als politischer Publizist. Ein Beitrag zur Geschichte des konservativen Nationalismus zwischen den beiden Weltkriegen, Nürnberg, Lorenz Spindler Verlag, 1967; K. KOSZYK, Deutsche Presse 1914-1945, Berlin, Colloquium, 1972, 251-256; G. BRÜHL, Herwarth Walden und »Der Sturm«, Köln, DuMont, 1983; J. BERGMANN, Die Schaubühne - Die Weltbühne 1905-1933. Bibliographie und Register mit Annotationen, München, Saur, 1991; R. STÖVER, Protestantische Kultur zwischen Kaiserreich und Stalingrad. Porträt der Zeitschrift »Eckart « 1906-1943, München, Studienbücher zur kirchlichen Zeitgeschichte, 2006; E. FISCHER, St. FÜSSEL (ur.), Geschichte des deutschen Buchhandels im 19. und 20. Jahrhundert, sv. 2, Weimarer Republik, 1. dio, München, K. G. Saur Verlag, 2007; W. BENZ (ur.), Handbuch des Antisemitismus. Judenfeindschaft in Geschichte und Gegenwart, Band 6, Publikationen, Berlin, De Gruyter, 2010; E. FISCHER, St. FÜSSEL (ur.), Geschichte des deutschen Buchhandels im 19. und 20. Jahrhundert, sv. 2, Weimarer Republik, 2. dio, München, K. G. Saur Verlag, 2012.
} 


\begin{tabular}{|c|c|c|c|}
\hline Das Tage-Buch & lijevi centar & 14.000 (1930.) & Rowohlt \\
\hline Sozialistische Monatshefte & lijevi centar & $5.000(1914)$. & G. Müller \\
\hline Hochland & $\begin{array}{c}\text { crkveno- } \\
\text { konzervativan }\end{array}$ & $10.000(1922)$ & J. Kösel \\
\hline Eckart & $\begin{array}{c}\text { crkveno- } \\
\text { konzervativan }\end{array}$ & $2.400(1931)$ & A. Hinderer \\
\hline Die Neue Rundschau & desni centar & $5.000(1933)$ & S. Fischer \\
\hline Die Hilfe & desni centar & $8.000(1929)$ & H. Beenken \\
\hline Süddeutsche Monatshefte $e^{28}$ & desni centar & 3.500 & $\begin{array}{c}\text { Süddeutsche } \\
\text { Monatshefte } \\
\text { G.m.b.H., München }\end{array}$ \\
\hline Die Literatur & desni centar & $3.000(1935)$ & DVA \\
\hline Europäische Revue & desni centar & $3.000(1931)$ & DVA \\
\hline Preußische Jahrbücher & desni centar & $2.000(1902)$ & $\begin{array}{c}\text { G. Stilke } \\
(1896 .-1935 .)\end{array}$ \\
\hline $\begin{array}{c}\text { Neue Literatur (do } 1931 . \\
\text { Die schöne Literatur) }\end{array}$ & $\begin{array}{c}\text { desno- } \\
\text { revolucionaran }\end{array}$ & $5.000(1931)$ & $\begin{array}{c}\text { Avenarius/HaVA od } \\
1929 .\end{array}$ \\
\hline $\begin{array}{l}\text { Deutsches Volkstum (do } \\
\text { 1917. Bühne und Welt) }\end{array}$ & $\begin{array}{c}\text { desno- } \\
\text { revolucionaran }\end{array}$ & $\begin{array}{c}3.000-5.000 \\
(1930 .-1932 .)\end{array}$ & $\begin{array}{c}\text { HaVA (Hanseatische } \\
\text { Verlagsanstalt) }\end{array}$ \\
\hline
\end{tabular}

\footnotetext{
${ }^{27}$ Terminologija političke orijentacije časopisa preuzeta je iz navedenih izvora. Pojmovi »desni/ lijevi centar« nisu upitni, oni i današnjem prosječnom čitatelju daju relevantnu i razumljivu informaciju o ideološkoj obojenosti časopisa. Međutim, upitno je koliko primjerice pojam »lijevo/desno - revolucionaran « doista daje pravu sliku o profilu časopisa. Kao primjer možemo navesti časopis Deutsches Volkstum koji je u navedenoj podjeli karakteriziran kao »desno - revolucionaran «, a koji je, nakon što je urednik postao uvjereni antisemit Wilhelm Stapel, redovito objavljivao priloge u kojima se negirao parlamentarizam i propagirala jaka država i teritorijalna ekspanzija na istok. Deutsches Volkstum »jedan je od najvažnijih časopisa konzervativne revolucije« [R. HERING, Deutsches Volkstum (1917-1941), u: W. BENZ (ur.), Handbuch des Antisemitismus. Judenfeindschaft in Geschichte und Gegenwart, sv. 6, Publikationen, Berlin, De Gruyter, 2010, 143], »na granici između konzervativnog i nacionalsocijalističkog mišljenja « (A. GERSTNER, Die Zeitschrift »Deutsches Volkstum«. Monatsschrift für das deutsche Geistesleben (1917-1938), u: M. GRUNWALD, U. PUSCHNER (ur.), Das konservative Intellektuellenmilieu in Deutschland, Bern, Peter Lang, 2003, 217), odnosno »antisemitski časopis « [P. GOSSENS, Der Kunstwart, Kulturzeitschrift, 1887-1932, u: W. BENZ (ur.), Handbuch des Antisemitismus. Judenfeindschaft in Geschichte und Gegenwart, sv. 7, Literatur, Film, Theater und Kunst, Berlin, De Gruyter, 2010, 272].

${ }^{28}$ Budući da je riječ o Weimarskoj Republici, treba napomenuti da je upravo u ovom časopisu u travnju/svibnju 1924. godine propagirana tzv. Dolchstoßlegende, teza o podlom »ubodu s leđa«. Radilo se o nastojanju političke desnice da odgovornost za poraz prebaci s vojne na političku razinu, odnosno o tvrdnjama da je njemačka vojska u 1. svjetskom ratu izgubila zbog izdajničkog djelovanja iznutra, zbog sabotaže socijaldemokratskih i komunističkih agitatora (usp. Velički, Njemački u politici..., 203). Zbog tih tvrdnji se glavni urednik časopisa Paul Nikolaus Cossmann morao braniti u nekoliko sudskih procesa koji su izazvali veliku pažnju javnosti [usp. H. - C. KRAUS (ur.), Konservative Zeitschriften zwischen Kaiserreich und Diktatur. Fünf Fallstudien, Reihe Studien und Texte zur Erforschung des Konservatismus, sv. 4, Berlin, Duncker \& Humblot, 2003].
} 
U trećem razdoblju Weimarske Republike postalo je očito da se društvo ne može nositi s rastućim problemima političke, socijalne i ekonomske naravi. ${ }^{29}$ Društvo je bilo prožeto nepremostivim stranačkim i ideološkim napetostima, ustavni nedostaci postajali su sve vidljiviji, a vladajući, kako je to opisao Karl Bracher, ${ }^{30}$ nisu shvatili da demokracija zahtijeva da i oni prihvate činjenicu da su kritički glasovi dio društvene zajednice i da se moraju uzeti u obzir. Njemački novinar, pisac i pacifist, dobitnik Nobelove nagrade za mir 1936. Carl von Ossietzky duhovnu je klimu 1932. godine prigodno opisao riječima da je javna kritika »izgubila na intenzitetu«, a da se novine »više ne mogu procjenjivati prema onome što pišu nego prema onome što prešućuju «. ${ }^{31}$

Nakon dolaska na vlast, Hitler je na stranačkom kongresu NSDAP-a ${ }^{32}$ u Nürnbergu 1933. godine izjavio da mu je umjesto "prava na slobodnu kritiku« cilj politički odgojni rad na njemačkom narodu. ${ }^{33}$ Time je potvrdio namjeru artikuliranu još u knjizi Mein Kampf da književna politika mora biti u službi odgoja cijelog naroda i nastavio indoktrinaciju i, još u vrijeme trajanja Weimarske Republike, započeto zatiranje slobodnog mišljenja. U studenom 1936. godine Goebbels je generalno zabranio književnu i umjetničku kritiku i nadomjestio je tzv. promatranjem umjetnosti (Kunstbetrachtung), i to pod izlikom »zaštite stvaralačkog genija od podrivačke kritike «. ${ }^{34} \mathrm{Na}$ kraju ovog poglavlja možemo istaknuti da,

»ako je u Weimarskoj Republici i postojala, kao protuteža antidemokratskim strujanjima, kritička publicistička javnost, onda se ona u svakom slučaju pokazala preslabom spriječiti da desni ekstremizam posegne za vlašću«. ${ }^{35}$

U navedenim okolnostima i opisanom duhovno-političkom ozračju tijekom četrnaest godina trajanja Weimarske Republike, djelovanje španjolskog filozofa José Ortege y Gasseta nije prošlo nezapaženo u njemačkoj javnosti. U nastavku, kako smo već naveli, fokus istraživanja usmjerit će se na recenzije, tj. prikaze Orteginih djela u njemačkim časopisima koji su se bavila književnošću.

\footnotetext{
${ }^{29}$ Usp. W. PYTA, Weimarer Republik, Opladen, Leske+Budrich, 2004.

${ }^{30}$ K. D. BRACHER, Das deutsche Dilemma, München, Piper, 1971.

${ }^{31}$ Die Weltbühne, 28 (1932) 13, 463-467 (29. ožujka 1932.).

${ }^{32}$ Stranački kongresi NSDAP-a u Nürnbergu u vrijeme trajanja tzv. Trećeg Reicha pripadaju u najveće skupove nacionalsocijalističke diktature. Međutim, za razliku od današnjeg poimanja stranačkog kongresa, Reichsparteitage nisu imali nikakvu programsku funkciju nego su služili isključivo propagandnim ciljevima. Radilo se o višednevnom insceniranju nacističkog pokreta i Adolfa Hitlera, o spektaklu koji je obilovao marševima i brojnim pseudoreligioznim elementima (usp. W. BENZ, H. GRAML, H. WEISS, Enzyklopädie des Nationalsozialismus, München, Dtv, 1997).

${ }^{33}$ K. D. BRACHER, W. SAUER, G. SCHULZ, Die nationalsozialistische Machtergreifung, Opladen, Westdt. Verl., 1960, 217.

${ }^{34}$ Th. ANZ, R. BAASNER, Literaturkritik. Geschichte, Theorie, Praxis, München, C. H. Beck, 2007, 229.

${ }^{35}$ E. FISCHER, St. FÜSSEL (ur.), Geschichte des deutschen Buchhandels im 19. und 20. Jahrhundert, sv. 2, Weimarer Republik, 1. dio, München, K. G. Saur Verlag, 2012, 79.
} 


\section{Djela Joséa Ortege y Gasseta u njemačkim časopisima od 1919. do 1933. godine}

Časopis koji je imao ključnu ulogu upoznavanja njemačke javnosti s djelom Ortege y Gasseta bio je Neue Rundschau. Radi se o časopisu koji je pokrenut još 1890. godine pod imenom Freie Bühne für modernes Leben i koji od 1904. izlazi pod sadašnjim imenom. Časopis je za vrijeme Weimarske Republike bio jedan od najvažnijih časopisa za modernu literaturu i esejistiku, ali objavljivao je priloge i iz umjetnosti, znanosti i politike. Aktivan je još i danas te se smatra jednim od najvažnijih europskih časopisa za kulturu. Za časopis su pisali, između ostalih, i Gerhart Hauptmann i Thomas Mann. Alfred Döblin također je pod pseudonimom početkom dvadesetih godina 20. stoljeća napisao niz članaka. Časopis je nakon 1919. godine, što se političke orijentacije tiče, pripadao u desni centar, osuđivao je ekstremno desne pozicije, a mogla se prepoznati i simpatija prema socijaldemokraciji. ${ }^{36}$ Pross $^{37}$ izdanja Neue Rundschau od 1929. do 1934. ubraja u organe društveno integrirane, građanske inteligencije.

Upravo je u Neue Rundschau 1924. godine izašao prilog o Ortegi y Gassetu kojega je pod naslovom Spanische Perspektiven napisao Ernst Robert Curtius. ${ }^{38}$ Curtius, poznati njemački romanist, u to vrijeme profesor na Sveučilištu u Heidelbergu, istaknuo je Ortega y Gassetovo spajanje njemačke i francuske kulture, a njegovo djelo El tema de nuestro tiempo vidi kao pokušaj formuliranja historijskog imperativa suvremene generacije da kulturu ponovo uklopi u život. Nadalje ćemo se detaljnije osvrnuti na recenziju knjige Pobuna masa (njem. Der Aufstand der Massen, španj. La rebelión de las masas) u Neue Rundschau, knjige koja se se u njemačkom prijevodu pojavila 1930. godine, a do 1940. godine naklada je dostigla 20.000 primjeraka.

Prvo nekoliko riječi o samoj knjizi. Pod pojmom mase Ortega y Gasset podrazumijeva kvantitetu prosječnih ljudi u društvu, a onaj dio društva koji svojim djelovanjem nadvisuju masu, Ortega opisuje kao elitu. Riječ je o manjini koja je u suglasju s opće priznatim normama bila duhovni vođa masa, čijom se pak pobunom poremetilo to aristokratsko načelo. Posljedica toga bio je, ukratko rečeno, povratak u barbarstvo. Ortega y Gasset navodi dva primjera, boljševizam i fašizam. Bitno je napomenuti da je nacionalsocijalizam u tom trenutku bio potencijalna opasnost, ali ne i realnost. Ortega y Gasset ukazuje na opasnosti koje prijete europskoj civilizaciji pobunom masa, a uzroke opasnosti vidi u propuštenim strukturnim reformama i političkim greškama.

Kao rješenje duhovno-moralne krize, on predlaže ujedinjenje europskih nacionalnih država. U Neue Rundschau je u lipnju 1931. godine objavljena re-

\footnotetext{
${ }^{36}$ Usp. F. SCHLAWE, Literarische Zeitschriften 1910-1933, Stuttgart, J. B. Metzlersche Verlagsbuchhandlung, 1962, 50.

${ }^{37}$ Usp. H. PROSS, Literatur und Politik, Olten u. Freiburg, 1963.

${ }^{38}$ E. R. CURTIUS, Spanische Perspektiven, Die neue Rundschau, 35 (1924) 1229-1248.
} 
cenzija Rudolfa Kaysera u kojoj on navodi da je riječ o »možda najznačajnijem filozofskom promišljanju povijesne situacije naše sadašnjosti«. ${ }^{39}$ Rudolf Kayser, njemački Židov, autor, povjesničar književnosti, autor, između ostaloga i biografije Alberta Einsteina, bio je glavni urednik časopisa od 1924. do 1933. godine, kada je smijenjen od strane nacionalsocijalističkog režima, nakon čega je emigrirao u Sjedinjene Američke Države. Kayser je u svom osvrtu na Pobunu masa doduše izrazio divljenje »osebujnim Orteginim načinom filozofiranja«, spomenuo je uzroke »svih kriza u današnjem životu« koje Ortega y Gasset vidi u pobuni masa i nestajanju elita u svim područjima života, ali je istovremeno bio mišljenja da je Ortega y Gasset podcijenio "povijesni proces, zakonitosti društvenih i privrednih promjena«. Kayser navodi da doduše postoji potreba za reformama, ali da zato »nije potrebno žrtvovati veliku i dugu prošlost«. Kayser je istovremeno poručio čitateljima da Ortega y Gasset put obnove vidi kao put u Europu i da želi Španjolsku ponovo integrirati u zapadnoeuropsku kulturu.

Osim Kayserove recenzije, detaljnije ćemo promotriti još dvije: recenziju Egona Viette u mjesečniku Die Literatur u lipnju 1931. godine, ${ }^{40}$ zatim recenziju Heinricha Jileka u istom časopisu, ali u studenom 1931. godine. ${ }^{41}$ Egon Vietta, dramatičar, kritičar, u svojim esejističkim književno-filozofskim promišljanjima pod utjecajem Martina Heideggera, autor više od dvadeset knjiga, izražava divljenje metodi kojom Ortega y Gasset konkretizira realnost, priznaje njegovu »stvaralačku sintetiku« sigurnost kojom Ortega y Gasset sagledava »duhovna strujanja vremena«. Heinrich Jilek, ukazujući i na drugu suvremenu literaturu, objašnjava da je inteligencija dospjela u krizu nekritičkim ponašanjem. To je započelo »obezvrjeđivanjem svih vrijednosti« i završit će »imenovanjem novih bogova ili padom u ništavilo«. Taj je proces započeo Francuskom revolucijom, udarna snaga masa ojačala je, a oslabjele su duhovne snage koje bi im se trebale suprotstaviti. Jilek pesimistično završava svoj osvrt primjedbom da napredovanje dotadašnjim putevima nije više moguće, a da novih nema. Časopis Die Literatur izlazio je od 1898. do 1923. godine pod imenom Das literarische Echo, izdavač je bila Deutsche Verlagsanstalt, a od 1923. godine časopis je pod imenom Die Literatur izlazio do 1942. godine. Što se političke orijentacije tiče, časopis se može smjestiti u desni centar, ${ }^{42}$ ali se isto tako radi o časopisu koji je opširno i objektivno sagledavao književna strujanja i pritom nastojao postići što veću neutralnost. ${ }^{43}$ Osim navedenih časopisa, do 1933. godine recenzije djela Ortege y Gasseta objavljivane su još u nekoliko časopisa. U Vergangenheit und Gegenwart se 1929. godine ${ }^{44}$ Fritz Kaphahn osvrnuo na spomenuto djelo El tema de nuestro tiempo (1923.) koje je na njemačkom pod naslovom

\footnotetext{
${ }^{39}$ Neue Rundschau, 6 (1931) 854-856.

${ }^{40}$ Die Literatur, lipanj 1931., 494.

${ }^{41}$ Die Literatur, studeni 1931., 69-71.

${ }^{42}$ Usp. Schlawe, Literarische Zeitschriften...

${ }^{43}$ Isto, 22.

${ }^{44}$ Vergangenheit und Gegenwart, 19 (1929) 94-106.
} 
Die Aufgabe unserer Zeit objavljeno 1928. godine u prijevodu Helene Weyl. Verganngenheit und Gegenwart bio je mjesečnik za nastavu povijesti i politički odgoj (Monatsschrift für Geschichtsunterricht und politische Erziehung) i izlazio je od 1911. do 1944. godine. Radilo se o strukovnom časopisu koji je dopuštao i kontroverzne pozicije. Od 1931. do 1936. godine urednik časopisa bio je Wilhelm Mommsen, povjesničar koji je javno, uz brojne ostale sveučilišne profesore, podržao Adolfa Hitlera i nacionalsocijalističku državu 11. studenog 1933. godine (Bekenntnis der Professoren an den deutschen Universitäten und Hochschulen zu Adolf Hitler und dem nationalsozialistischen Staat). Autor recenzije Fritz Kaphahn u navedenom je časopisu istaknuo to djelo Ortege y Gasseta kao jedno od malobrojnih za koje vjeruje da bi moglo spasiti europski humanizam.

Nadalje valja spomenuti da je u mnoštvu prevodilaca djela Ortege y Gasseta, sam Ortega y Gasset istaknuo već spomenutu Helenu Weyl. Naime, Helena Weyl, supruga poznatog matematičara Hermanna Weyla, dvadesetih je godina dvadesetog stoljeća, kada je njezin suprug dobio poziv da održi nekoliko predavanja u Madridu i Barceloni, upoznala Ortegu y Gasseta te je, privučena njegovim filozofskim promišljanjima i briljantnim stilom, odlučila prevesti nekoliko njegovih djela na njemački jezik. Tako je Weyl, između ostaloga, na njemački prevela i sljedeća Ortegina djela: Der Aufstand der Massen (La rebelión de las masas), Die Aufgabe unserer Zeit (El tema de nuestro tiempo), Buch des Betrachters (El Espectador), Um einen Goethe von innen bittend (Pidiendo un Goethe desde dentro). Ortega y Gasset je i sam istaknuo visoku razinu profesionalnosti i ljepotu prijevoda Helene Wely svojih djela na njemački jezik. Tako je istaknuo da su za brojna izdanja njegovih djela na njemački jezik uvelike zaslužni upravo prijevodi Helene Weyl koja je,

"gramatičku toleranciju njemačkog jezika dovela do krajnosti kako bi prenijela upravo ono što u mojem načinu govora nije njemačko. Na taj način čitatelj bez poteškoća može izvoditi duhovne geste koje su u stvarnosti španjolske. Tako se čitatelj malo odmara od samoga sebe i zabavlja ga što se jednom može osjećati kao netko drugi. $\aleph^{45}$

Die Aufgabe unserer Zeit recenzirana je, osim u spomenutom časopisu Vergangenheit und Gegenwart, i u časopisu Archiv für Sozialwissenschaft und Sozialpolitik. ${ }^{46}$

Još su neki osvrti na Ortegina djela izašli u već spomenutom časopisu Die Literatur. ${ }^{47}$ Zanimljivo je spomenuti da se na Ortegine studije o ljubavi osvrnuo

\footnotetext{
${ }^{45}$ J. ORTEGA Y GASSET, Glanz und Elend der Übersetzung, u: J. ORTEGA Y GASSET, Gesammelte Werke (1978), Stuttgart, Deutsche Verlagsanstalt, 1937, 150.

${ }^{46}$ B. VON WIESE, José Ortega y Gasset, Die Aufgabe unserer Zeit, Archiv für Sozialwissenschaft und Sozialpolitik, 62 (1929) 635-637.

${ }^{47}$ M. BRUSSOT, Die Revolution im spanischen Schrifttum, Die Literatur, 33 (1931-1932) 680682; W. BONSELS, Über die Liebe, Die Literatur, 35 (1932-1933) 557-560.
} 
i jedan stručni časopis za psihologiju, Zeitschrift für Psychologie. ${ }^{48} \mathrm{U}$ toj je recenziji, koja je doduše izašla već nakon sloma Weimarske Republike, Ortega y Gasset opisan kao odlično informirani psiholog. Osvrti na njegova djela izašli su, osim u navedenim, i u još nekim časopisima kao što su npr. Die Tatwelt ${ }^{49}$ i Die Frau..$^{50}$ Die Frau je bio časopis koji je izlazio od 1893. do 1944. godine, a do 1933. godine ga je izdavao Bund Deutscher Frauenvereine. Taj je savez bio zapravo krovna organizacija građanskog ženskog pokreta na čijem je čelu neko vrijeme bila i poznata aktivistica za ženska prava Helene Lange. Svakako treba obratiti pažnju na još tri časopisa u kojima su u Njemačkoj u vrijeme Weimarske Republike, odnosno neposredno nakon njezinog sloma, izašli tekstovi o Ortegi y Gassetu.

Svakako treba spomenuti časopis Deutsche Rundschau. Treba ga razlikovati od već spomenutog Neue Rundschau. U Deutsche Rundschau je 1934. Otto von Taube napisao kratak osvrt na Orteginu knjigu El Espectador (njem. Buch des Betrachters ${ }^{51}$ u prijevodu Helene Weyl), u kojem se Ortega opisuje kao jedan od najvažnijih španjolskih mislilaca.

Drugi je časopis Hochland ${ }^{52} \mathrm{u}$ kojem je Ernst Robert Curtius, u sklopu svoje rasprave o španjolskim kulturološkim problemima, zaključio da je s Ortega y Gassetom, uz ostale autore, Španjolska ponovo ušla u krug duhovnih velesila.

Treći časopis je Europäische Revue ${ }^{53} \mathrm{u}$ kojem je Curtius također 1926. godine napisao članak o Ortegi. Deutsche Rundschau osnovan je 1874. godine i izlazio je jednom mjesečno u izdanju Berliner Gebrüder Paetel Verlag. Časopis je zabranjen 1942. godine, a nastavio je izlaziti od 1946. do 1964. godine. Časopis je, prema vlastitim navodima, htio na temelju nacionalnog, umjerenog liberalizma i kulturnog konzervativizma dati pregled o duhovnim kretanjima današnjice. Hochland je bio časopis katoličke orijentacije koji je izlazio od 1903. do 1941. godine, te ponovo od 1946. do 1971. godine. Neki autori smatraju taj časopis »najvažnijim časopisom duhovnog otpora « ${ }^{54} \mathrm{u}$ vrijeme nacionalsocijalističke diktature. Drugi autori su znatno suzdržaniji kad je riječ o duhovnom otporu nacističkom režimu i ukazuju da je u časopisu propagiran Anschluss Austrije, ${ }^{55}$ a neki pak priznaju da je nacionalsocijalizam bio vrlo malo privlačan autorima koji su pisali za Hochland, ali isto tako smatraju da se pojam »otpora« ne može

\footnotetext{
${ }^{48}$ A. HEIDENHAIN, Über die Liebe, Rezension, Zeitschrift für Psychologie, 138 (1936) 378-379.

${ }^{49}$ E. ERDSIEK, Schiffbrüchige richten über Ortega, Die Tatwelt, 8 (1932-1933) 189-193.

${ }^{50}$ A. KLAPHECK-STRÜMPELL, Der geistige Führer des neuen Spanien über die Frau, Die Frau, 39 (1932) 350-354.

${ }^{51}$ O. VON TAUBE, Buch des Betrachters, Rezension, Deutsche Rundschau, 240/1934, 124-125.

${ }^{52}$ E. R. CURTIUS, Spanische Kulturprobleme der Gegenwart, Hochland, 23 (1926) 678-691.

${ }^{53}$ E. R. CURTIUS, Jose Ortega y Gasset, Europäische Revue, 1926, 22-26.

${ }^{54}$ Usp. K. ACKERMANNN, Der Widerstand der Monatsschrift Hochland gegen den Nationalsozialismus, München, Kosel, 1965, 100.

${ }^{55}$ Usp. P. KÖPF, Schreiben nach jeder Richtung. Goebbels-Propagandisten in der westdeutschen Nachkriegspresse, Berlin, Ch. Links, 1995, 86.
} 
bez kritičkih tonova upotrijebiti kad je riječ o tekstovima koji su izlazili u njemu. ${ }^{56}$

Časopis Europäische Revue koji se prilikom osnivanja izjasnio politički neutralnim, možemo pribrojiti u konzervativne časopise. ${ }^{57} \mathrm{Za}$ časopis su, između ostalih pisali i Theodor Heuß, Hugo von Hofmannsthal, Thomas Mann, Rainer Maria Rilke, Carl Schmitt. Tekstove su objavljivali i strani autori; osim Ortege y Gasseta, primjerice, i Winston Churchill i Aldous Huxley. ${ }^{58}$ Međutim, nakon dolaska Hitlera na vlast, nacisti su preuzeli dobar dio financiranja časopisa i koristili su ga kao platformu za propagiranje svojih ideja. Tako je časopis i uspio izlaziti do 1944. godine.

\section{Zaključak}

Recenzije djela Ortege y Gasseta u razdoblju Weimarske Republike objavljivane su u vodećim časopisima za kulturu i književnost toga vremena. Radilo se o časopisima različitih političkih orijentacija is nakladom između 3.000 i 5.000 primjeraka (usp. tablicu 2). Međutim, iako su u središtu interesa ovoga rada, kako smo već naveli, recenzije, tj. prikazi djela Ortege y Gasseta u njemačkim časopisima koji su se bavili književnošću, u sveukupnost recepcije autorovih djela u vrijeme Weimarske Republike, svakako bi trebalo ubrojiti i radove koje je napisao sam Ortega y Gasset i koji su u tom razdoblju objavljeni u časopisima. Stoga treba spomenuti i podatak da je do 1933. godine objavljeno sedam njegovih radova, i to tri u Neue Rundschau, četiri u Europäische Revue i po jedan članak u Der Querschnitt i Philosophie und Leben. ${ }^{59}$

Na prva dva časopisa već smo se opširnije osvrnuli, no upravo ova druga dva zaslužuju dodatnu pozornost iz dva razloga. Der Querschnitt je važan stoga što je riječ o časopisu koji je od svih dosad spomenutih časopisa imao najveću nakladu; 1932. godine tiskan je u više u 30.000 primjeraka ${ }^{60}$ Osim Orteginih članaka, u tom časopisu su objavljivani i tekstovi brojnih drugih poznatih imena, da spomenemo samo neke: Gabriele d' Annunzia, André Gida, Ernesta

\footnotetext{
${ }^{56}$ Usp. F. DIRSCH, Das »Hochland «. Eine katholisch-konservative Zeitschrift zwischen Literatur und Politik 1903-1941, u: H.-C. KRAUS (ur.), Konservative Zeitschriften zwischen Kaiserreich und Diktatur. Fünf Fallstudien. Reihe Studien und Texte zur Erforschung des Konservatismus, 4. Berlin, Duncker \& Humblot, 2003, 85-96.

${ }^{57}$ Usp. Kraus (ur.), Konservative Zeitschriften...

${ }^{58}$ Usp. H. T. HAKL, Eranos. An Alternative Intellectual History of the Twentieth Century, Kingston, McGill-Queen's University Press, 2013.

${ }^{59}$ Usp. F. JUNG-LINDEMANN, Zur Rezeption des Werkes von José Ortege y Gasset in den deutschsprachigen Ländern, Frankfurt am Main, Peter Lang, 2001.

${ }^{60}$ Chr. SCHULZE, Der Querschnitt (1921-1936), u: H.-D. FISCHER (ur.), Deutsche Zeitschriften des 17. bis 20. Jahrhunderts, Pullach, Verlag Dokumentation, 1973, 386.
} 
Hemingwaya, James Joyca i Georga B. Shawa. Prilozi objavljivani u časopisu obuhvaćali su širok raspon tema, od glazbe i teatra, do plesa filma i sporta. ${ }^{61}$

Drugi pak časopis, Philosophie und Leben izlazio je od 1925. do 1933. godine, a radilo se o časopisu za filozofiju čiji je urednik bio August Messer, njemački filozof koji je 1930. godine bio i urednik i uvodničar Nietzscheovih djela u dva sveska. ${ }^{62}$ Tome treba pribrojiti i prijevode djela Ortege y Gasseta u vrijeme Weimarske Republike. Tako se je, primjerice, Pobuna masa (u njemačkom prijevodu Der Aufstand der Massen) na njemačkom tržištu pojavila 1930. godine, vrlo brzo nakon španjolskog originala, te je do 1940. (dakle dijelom i u vrijeme Weimarske Republike) tiskana u nakladi od 20.000 primjeraka.$^{63}$ El tema de nuestro tiempo, u njemačkom prijevodu Helene Weyl i u izdanju Deutsche Verlagsanstalt tiskana je 1930. godine te je do 1943. godine dostigla nakladu od 10.000 primjeraka. ${ }^{64}$

Stoga možemo zaključiti da je Ortega y Gasset u Njemačkoj u vrijeme Weimarske Republike, ako mjerimo prema nakladi časopisa, odnosno prodanih knjiga, definitivno pronašao svoj put do njemačke čitateljske publike. Međutim, istovremeno se mora istaknuti da se puno više o recepciji Ortege y Gasseta može zaključiti promatrajući publikacije koje su pisale o njemu ili u kojima je on objavljivao svoje tekstove, nego prijevodi knjiga. Naime, časopisi, posebice oni koji se bave književnošću, obraćaju se čitateljima višeg obrazovanja nego što je to slučaj s prijevodima, a i naklade takvih časopisa (iako se možda smatraju velikima, budući da je riječ o časopisima za kulturu i književnost), ipak u rijetkim slučajevima prelaze nakladu od 5000 primjeraka. Osim toga upada u oči da je Ortega y Gasset u vrijeme Weimarske Republike objavio samo jedan tekst u stručnom časopisu za filozofiju. Niti nakon pada Weimarske Republike, pa sve do danas, usprkos brojnim prijevodima djela Ortege y Gasseta na njemački i »velikom uspjehu koji je postigao kao gotovo nijedan drugi filozofski autor na stranom jeziku«, ${ }^{65}$ na njemačkom govornom području u stručnoj filozofskoj literaturi gotovo i nema rasprava koje se bave pojašnjenjem, analizom i kritikom, ukratko idejama njegova stvaranja. ${ }^{66}$

Na samom kraju, budući da je riječ o recepciji njegovih djela u Njemačkoj, možemo samo ukratko spomenuti i utjecaj Nijemaca i njemačke kulture na stvaralaštvo Ortege y Gasseta. Naravno, riječ je o kompleksnoj temi koja je bila predmet istraživanja brojnih autora ${ }^{67}$ i o temi koja prelazi granice interesa

\footnotetext{
${ }^{61}$ Usp. isto.

${ }^{62}$ F. NIETZSCHE, Werke in zwei Bänden. Ausgewählt und eingeleitet von August Messer, Leipzig, Kröner Verlag, 1930.

${ }^{63}$ Usp. F. JUNG-LINDEMANN, Zur Rezeption des Werkes von José Ortege y Gasset in den deutschsprachigen Ländern, Frankfurt am Main, Peter Lang, 2001, 65.

${ }^{64}$ Usp. isto, 65.

${ }^{65}$ Isto, 181.

${ }^{66}$ Usp. isto, 188.

${ }^{67}$ Od američkih autora mogu se istaknuti R. McCLINTOCK, Man and His Circumstances. Ortega as Educator, New York, Teachers College Press, 1971; R. GRAY, The Imperative of Mo-
} 
ovoga rada. Međutim, ne možemo ne spomenuti mladenačku očaranost Ortege y Gasseta njemačkom kulturom kada je, opisujući svoj boravak u Njemačkoj, napisao da je »godinama nakon toga bio zanesen njemačkom znanošću dok se gotovo nije utopio « ${ }^{68}$ te da je shvatio »što Španjolska mora učiniti, mora apsorbirati njemačku kulturu, cijelu je progutati - kao nov prekrasan izvor podrške ${ }^{69}{ }^{69}$ Rossi $^{70}$ je pak njemački utjecaj na Ortegu y Gasseta sažeo sljedećim riječima:

»Ortega je iz Njemačke donio predodžbu o filozofiji kao strogom i ozbiljnom predmetu, kao što su i prirodne znanosti, predodžbu o filozofiji kao institucionaliziranoj disciplini koja od onoga koji se želi njome baviti zahtijeva brižljivo školsko obrazovanje. Tehnika mora kontrolirati unutrašnje izljeve. Osim toga, iz Njemačke se vratio s uvjerenjem da je filozofija instrument nacionalnog odgoja. «11

Njemački su čitatelji svojim interesom za stvaralaštvo španjolskog filozofa već i u razdoblju Weimarske Republike uzvratili Ortegi y Gassetu njegovo štovanje njemačke filozofije i kulture.

dernity. An Intellectual Biography of José Ortega y Gasset, Berkeley - Los Angeles - London, University of California Press, 1989, a od hrvatskih T. KRZNAR, Filozofija kao briga za cjelinu - edukacijski uvidi u filozofiji Ortege y Gasseta, u: J. MILINKOVIĆ - B. TREBJEŚANIN (ur.), Implementacija inovacija u obrazovanju i vaspitanju - izazovi i dileme, Zbornik radova naučnog skupa, Beograd, 2014, 47-63 te T. KRZNAR, Lov - sport ili destrukcija? Tragom misli Joséa Ortege y Gasseta, Filozofska istraživanja, 29 (2009) 3, 461-475.

${ }^{68}$ J. ORTEGA Y GASSET, Phenomenology of Arts, prev. Philip W. Silver, New York, W. W. Norton, $1975,24$.

${ }^{69}$ Isto, 29.

${ }^{70}$ A. ROSSI, Sprache und Philosophie bei Ortega y Gasset, u: O. LEON, F. SALMERON (ur.), Schriften zur Rechtstheorie, sv. 136, Philosophie und Rechtstheorie in Mexiko, Berlin, Duncker \& Humblot Berlin, 1989, 181-194.

${ }^{71}$ Isto, 185. 


\section{Damir Velički* \\ Reception and reviews of works by José Ortega y Gasset in German journals during the Weimar Republic \\ Summary}

Following the theoretical starting points clarifying the term "reception" based on the theory of reception itself and its representatives, especially Jauss and Iser, and the concept of review, the paper also analyses historical and social situations. The interest of the research is, content-wise, limited to reviews of books by the Spanish philosopher José Ortega y Gasset in German literary journals during the time of the Weimar Republic, 1919 - 1933. The findings on how an author's works were reviewed and in which journals they appeared with regard to their character, ideological, i.e. religious orientation of these journals, cast additional light on the works themselves as well, i.e. on the author as a whole. Because of this, the political situation in Germany during this period of history was in need of further and more detailed examination. After a thorough analysis, we concluded that during the time of the Weimar Republic, judging by the copies of the journals in circulation, i.e. books sold, Ortega y Gasset has definitely found his way to Germany's readers.

Keywords: José Ortega y Gasset, reception, literature journals, Weimar Republic, philosophy.

(na engl. prev. Goran Brkić)

\footnotetext{
* Damir Velički, PhD, Assistant Professor; Department of German Language Teacher Education - Intercultural German Studies, Faculty of Teacher Education, University of Zagreb; Address: Savska 77, HR-10000 Zagreb, Croatia; E-mail: damir.velicki@ufzg.hr.
} 